\title{
Survival of White Blood Cells of Mice (Mus Musculus L) on Interval AD with CD Post Gamma Radiation Co-60
}

\author{
Gusti Ngurah Sutapa \\ Udayana University, Denpasar, Indonesia \\ Corresponding author email: sutapafis97@unud.ac.id \\ Ni Nyoman Ratini \\ Udayana University, Denpasar, Indonesia \\ Ni Kadek Nova Anggarani \\ Udayana University, Denpasar, Indonesia
}

\author{
I Gde Antha Kasmawan \\ Udayana University, Denpasar, Indonesia
}

\begin{abstract}
One of the phenomena of the low-dose radiation effect is the radio adaptation response which is an important part of the response of molecules, cells, and body tissues to ionizing radiation. The phenomenon of radio adaptation response is a response that occurs when changes in gene expression can be induced by exposure to low doses of radiation $(<0.5 \mathrm{~Gy})$. Changes in the expression of this gene under certain circumstances serve to protect cells against the effects caused by subsequent exposure to higher doses of radiation, so this situation is known as an adaptive response or radio adaptation response. Cells can respond to very low doses of radiation with some changes in gene expression. Beginning with the administration of radiation to cells with a very low dose, known as the adaptation dose $(A D)$, and then in a short period being given a larger dose of radiation, known as the challenge dose $(C D)$, there was a decrease in the number of induced chromosome aberrations when compared to cells that were not irradiated at an adapted dose. The purpose of this study was to obtain a radiotherapy method that could show a reduction in the patient's dose.

Keywords---adaptation dose, cell survival, challenge dose, radiotherapy method, white blood
\end{abstract}

\section{Introduction}

Blood is an important part of the body's circulatory system. Blood consists of two parts, namely the liquid part (blood plasma) and blood cells. Blood cells include erythrocytes, leukocytes, and platelets. Leukocytes function as the body's immune system. Erythrocytes together with hemoglobin function in tissue oxygenation and platelets play a role in the blood clotting system. These blood cells are produced in the bone marrow. The radiosensitivity of various types of blood cells varies, the most sensitive cells are lymphocytes and the most resistant cells are erythrocytes (Slonane, 2003). The whole body radiation dose of about 0.5 Gy which is called low dose radiation can cause a decrease in the process of forming blood cells so that the number of blood cells will decrease. This decrease in the number of blood cells will have a very serious impact if it is not treated immediately because blood has an important role in the functions of the human body such as immunity, oxygenation, hemostasis, and other roles (Pearce, 2005).

Several studies on the effects of low dose radiation have shown a shift in the three main paradigms of radiation biology. One of them is a phenomenon known as adaptation response (Alatas, 2006). The adaptation response is the induction of a low radiation dose that allows changes to the mechanisms of the cellular and molecular systems. 
Under certain conditions, it can protect cells against the effects caused by the next high radiation dose received. The phenomenon of radio adaptation response is a response that occurs when changes in gene expression can be induced by exposure to low doses of radiation around $<0.5 \mathrm{~Gy}$. Changes in gene expression in certain circumstances serve to protect cells against the effects caused by subsequent radiation exposure at higher doses (Kadhim et al., 2004).

Through the micronuclei test, the ability of cells to repair DNA fractures caused by radiation can be determined. As a result of radiation induction, micronuclei generally contain fragments of chromosomes that do not undergo repair. To determine the dose exposure and low dose rate on the ability of cells to repair chromosomal breaks, research was conducted on human skin cells. In this study, the frequency of micronuclei per cell in the radiation dose adaptation was $0.5 \mathrm{~Gy}$ with a dose rate of $2.5 \mathrm{mGy} / \mathrm{min}$. After 0 hours and 5 hours, they were irradiated again with a dose of $4 \mathrm{~Gy}$ at a dose rate of $1.8 \mathrm{~Gy} /$ minute. The results showed that the low dose and dose rate can stimulate cells to increase their ability to repair chromosomal damage, thereby reducing the consequences of subsequent radiation exposure. An important biological variable can be shown that chromosomal damage is not always dosing proportional (Hindséna et al., 2001; Confer et al., 1985).

This research was conducted on four sample groups of mice irradiated with gamma Co-60 with a dose challenges of $1 \mathrm{~Gy} ; 1.5 \mathrm{~Gy} ; 2 \mathrm{~Gy} ; 2.5 \mathrm{~Gy}$ and $3 \mathrm{~Gy}$. In the fourth group of mice, the five doses of the challenges were given 5 hours after receiving the adaptation dose of $0.1 \mathrm{~Gy}$. The result was that the lowest decrease in the number of leukocytes occurred in the fourth sample group of mice. This indicates that the adaptation response increases when there is a time interval between the dose of adaptation and the dose of challenges (Sutapa et al., 2014). Also, this study used an adaptation dose of $0.1 \mathrm{~Gy}$, followed by a dose of $1 \mathrm{~Gy}, 2 \mathrm{~Gy}$ and $3 \mathrm{~Gy}$ which was able to stimulate cells to increase their ability to recover cells after Co-60 radiation. The number of leukocytes has decreased from day 1 to day 30. Furthermore, after passing the 30th day to the 60th day the number of leukocytes has increased. These results differ from the number of leukocytes in mice with the treatment doses of $1 \mathrm{~Gy}, 2 \mathrm{~Gy}$ and 3 Gy without the dose adaptation. This shows the rate of decrease in the quantity of leukocytes from day 1 to day 30 which is faster without an adapted dose compared to using an adapted dose. It can be stated that, in the absence of an adapted dose, radiation has a damaging effect on stem cells and precursor cells in the bone marrow thereby decreasing the number of blood cells in their spread (Jacks \& Weinberg, 2002; Ambrogini et al., 2000).

According to Okazaki et al. (2005); Kadhim et al. (2004), the radio adaptation response is a biological phenomenon in which resistance to radiation is obtained by administering one or several initial doses of radiation at a very low dose. In radiation fields, the adaptive response becomes a synonym for radioresistance which can alter the biologic effectiveness of subsequent radiation at larger doses. One of the parameters that affect the rate of radio adaptation response is the interval between $\mathrm{AD}$ and $\mathrm{CD}$. Based on the results of the research above and the mechanism of the radio adaptation response, it is necessary to study the survival of white blood cells in mice against the AD interval with CD after Gamma Co-60 radiation (Castillejos et al., 2007; Jacob et al., 2003).

\section{Meterials and Methods}

Radiotherapy was carried out at the Sanglah Hospital Radiotherapy Installation using a Co-60 Teleterapy aircraft and blood tests for mice were carried out at the Bali Provincial Laboratory. Radiation was carried out at an adapted dose of $0.1 \mathrm{~Gy}$ in all treatment groups except the control group. Followed by a challenge dose of $3 \mathrm{~Gy}$ with time intervals of $0,1,2,3,4$, and 5 hours. After the implementation of the radiation is complete, it is followed by taking and counting the quantity of leukocytes and their components by taking a blood sample of mice through a vein in the eye. The blood is compressed into the EDTA tube until $\pm 0.5 \mathrm{cc}$ is obtained and the blood in the tube is shaken so that the blood and EDTA are evenly mixed. The blood sample is sucked from the EDTA tube using a hemocytometer pipette (Schwartz et al., 2013; Donovan et al., 2007). The Turk solution is also sucked using a hemocytometer pipette. This is a dilution process with the ratio of a blood sample to Turk solution being 1:50. The goal is to destroy the red blood cells so that only leukocytes can be seen on the microscope. Then the results of the mixture of blood with the Turk solution are put on a shaker for 5 minutes. Furthermore, the mixed blood is entered into the hemocytometer. The number of leukocytes was observed under a microscope and counted by a laboratory counter. The data is analyzed by normality test first for data that is normally distributed. To analyze the differences, the Anova statistic (analysis of variance) was used. Anova is better known as the F-Test (Fisher Test) at $=5 \%$, to see the significant difference in each dose of adaptation to the leukocyte challenge dose (Hall \& Giaccia, 2006; Mayerni et al., 2009). 


\section{Results and Discussion}

The results of the calculation of the leukocyte quantity of mice for control and treatment can be represented in a graphical form as shown in Figures 1, 2 and 3. In this research, mice irradiated at the 3 Gy challenge dose is a dose range lower than $7 \mathrm{~Gy}$ which is the $\mathrm{LD}_{50 / 30}$ value of mice (Romero et al., 1993; Schattner et al., 1981).

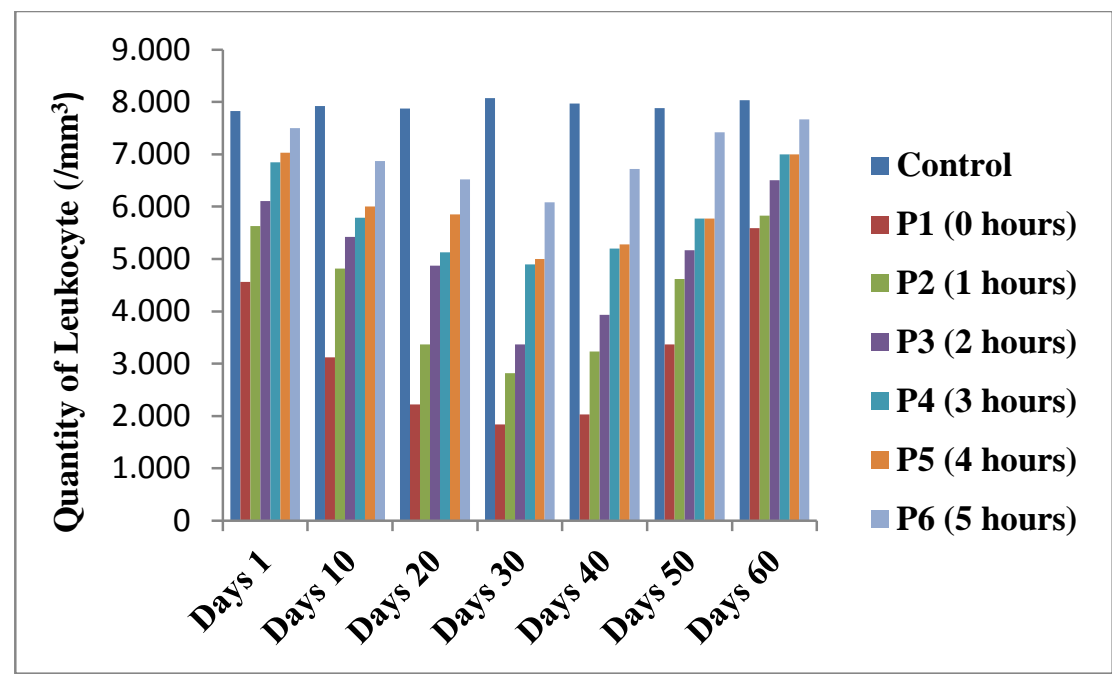

Figure 1. Quantity of leukocytes

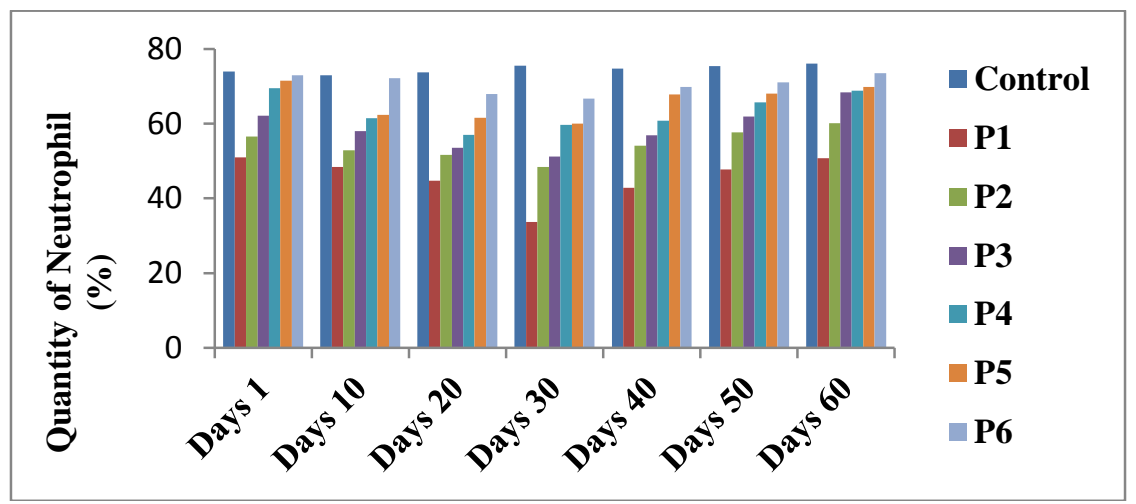

Figure 2. Quantity of neutrophils components

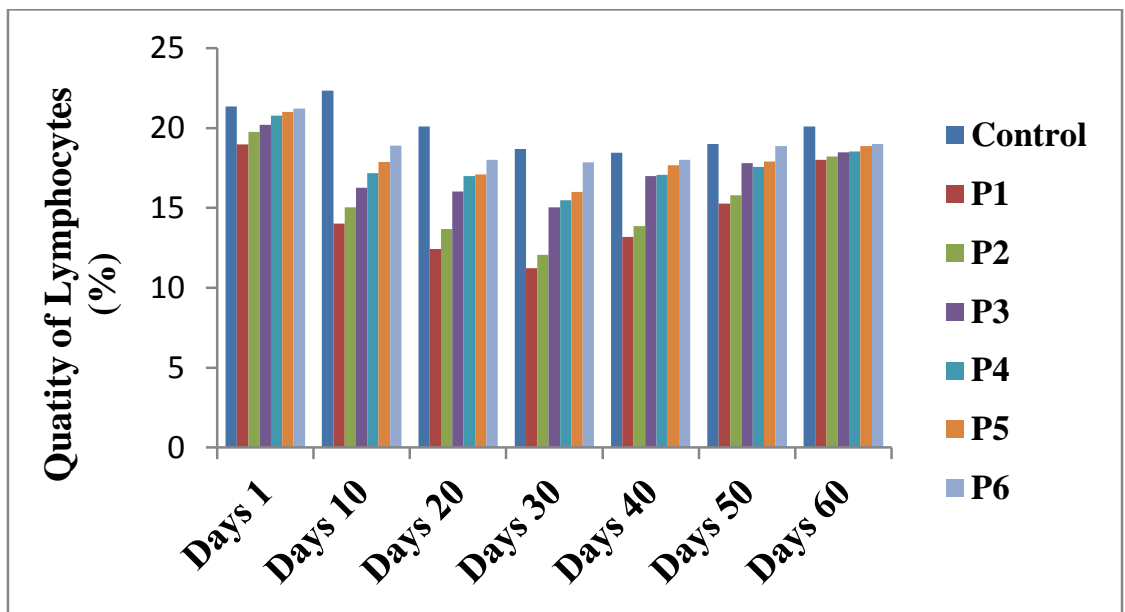

Figure 3. Quantity of lymphocytes components 
The results of this research showed that the quantity of leukocytes in control mice was $7.825-8.375 \times 103 / \mu$, which was not much different from the results of the study from Harahap (2008), which ranged from $5-11 \times 103$ $/ \mu 1$. Graphic representation as shown in Figure 1, in general, the quantity leukocyte for P1 to P6 are below the control leukocyte quantity. The decrease in the quantity of total leukocytes in the circulation due to radiation is caused by damage to the hematopoietic system (Desprez, 2011). Radiation can also reduce the quantity of leukocytes depending on radiosensitivity and cell survival. Radiation interactions with mammalian cells can induce a large number of DNA damage, such as single-strand breaks (SSB), double-strand breaks (DSB), various types of base damage, DNA cross-links, and local combinations of all these damages (Sisworo, 2007). Radiation causes inhibition or cessation of the hematopoietic process, which causes the supply of blood cells to decrease and there is a decrease in the quantity of leukocytes in the blood. It was stated that a dose of 2-10 Gy is the scope of hematopoietic damage (bone marrow syndrome), with symptoms of decreased total leukocyte count (leucopenia) (Sulaeman et al., 2018; Kusumayanti \& Dewantari, 2017).

Meanwhile, the lowest leukocyte survival occurred at P1 and there was an increase in leukocyte survival from P2 to P6. It can be seen that the AD 0.1 Gy has resulted in changes in the adaptive response to radiation spontaneously, and the changes increase when the mice are given a rest period of 1 hour, 2 hours, 3 hours, 4 hours, and 5 hours after AD 0.1 Gy. The possibility of cell damage due to dose adaptation is repaired through the recovery process. With the increase in the quantity of leukocytes due to the time interval of administering $\mathrm{AD}$ with $\mathrm{CD}$, it can reduce effects such as fatigue, changes in peripheral blood cells, fever (if the brain area is receiving radiation), headaches, dizziness, nausea, vomiting, and diarrhea to baldness after gamma Co-radiation. 60 (Djan et al., 2014).

Figure 1 also shows that the quantity of leukocytes from the first day after radiation decreased steadily until day 30 which was the lowest leukocyte quantity, but with time after radiation (day 40) there was an increase in leukocyte survival until day 60 approached control leukocyte count. Administration of low doses $(0.1 \mathrm{~Gy})$ was found to stimulate cells to increase their ability to repair damage and increase the resistance of cells to the next greater radiation. The adaptive response is a biological phenomenon, increasing resistance to radiation is obtained by administering one or several initial doses of radiation at very low doses. In a radiation field, the adaptive response becomes radio resistant, which can alter the biological effectiveness of subsequent radiation at larger doses (Deprez, 2011). The longer the time interval was given between DA and DC, the higher the percentage of leukocyte strength. Low-dose radiation has been shown to increase the ability of normal mammalian cells, including bystander cells (cells that are not exposed to radiation), to carry out chromosomal repair and also induce death through apoptosis (Okazaki et al., 2005). The longer the time interval between AD and CD, the greater the response to an increase in the quantity of leukocytes. This provides an opportunity for the cell's resistance response to the next greater radiation to take place. From these findings, information was obtained that the time interval between administration of AD and CD determines the leukocyte response. The same response may occur in other organs or tissues (Djan et al., 2014).

The results of the research for the components of leukocytes, especially neutrophils and lymphocytes, show a picture and response that is almost the same as the quantity of leukocytes. According to Lusiyanti \& Syaifudin (2008), these two leukocyte components can be used as general hematopoietic indicators of radiation exposure. However, this is not the case with other leukocyte components such as monocytes, eosinophils, and basophils shown in Figures 4, 5, and 6 below.

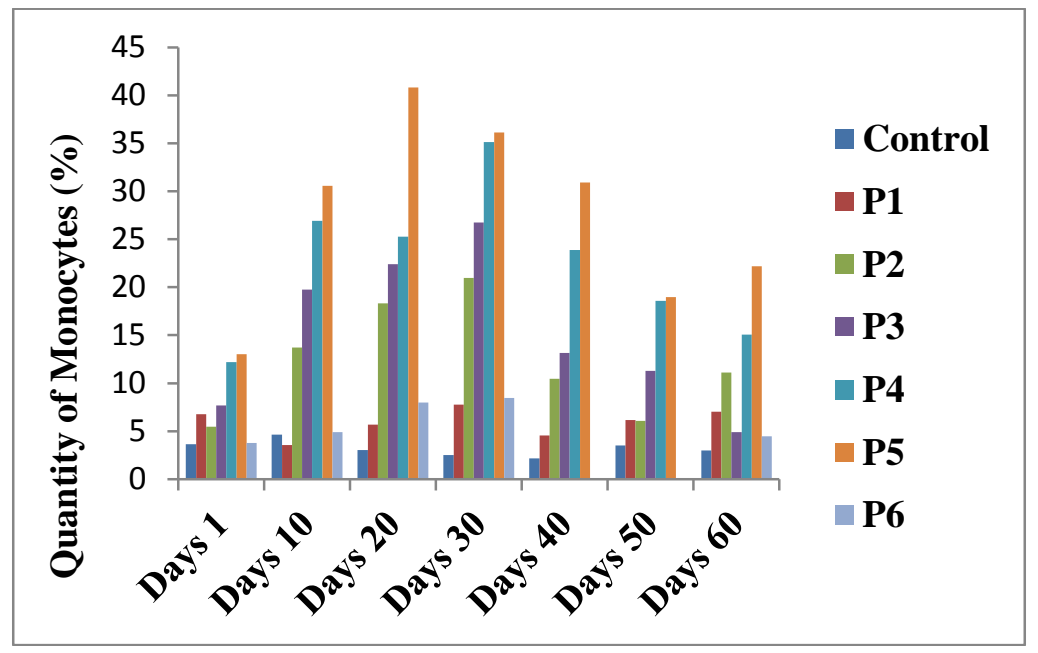

Figure 4. Quantity of monocytes components 


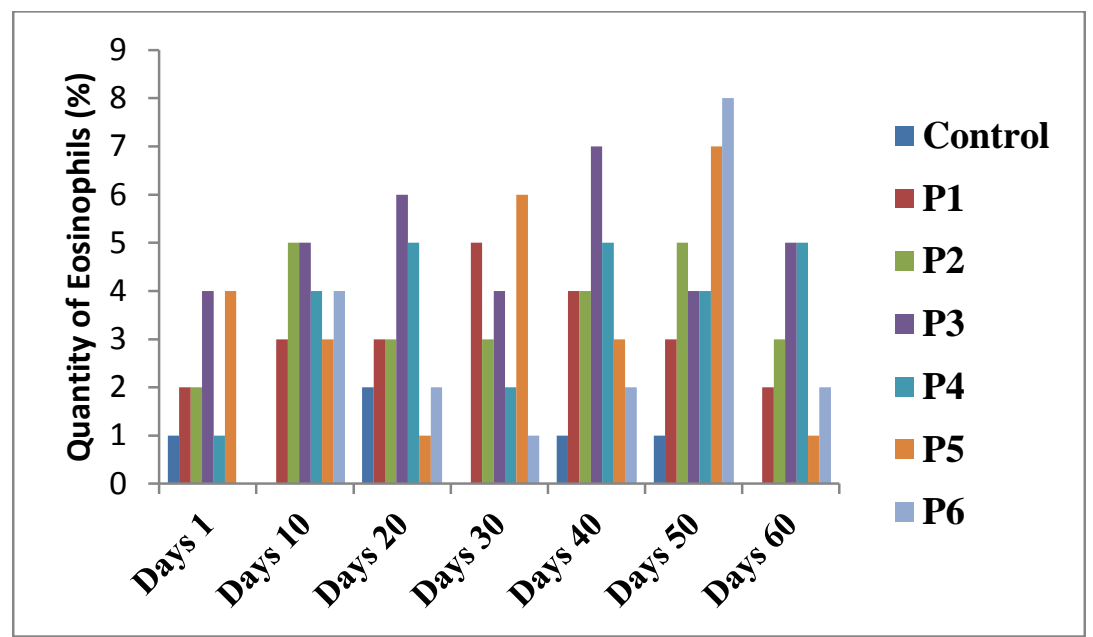

Figure 5. Quantity of eosinophils components

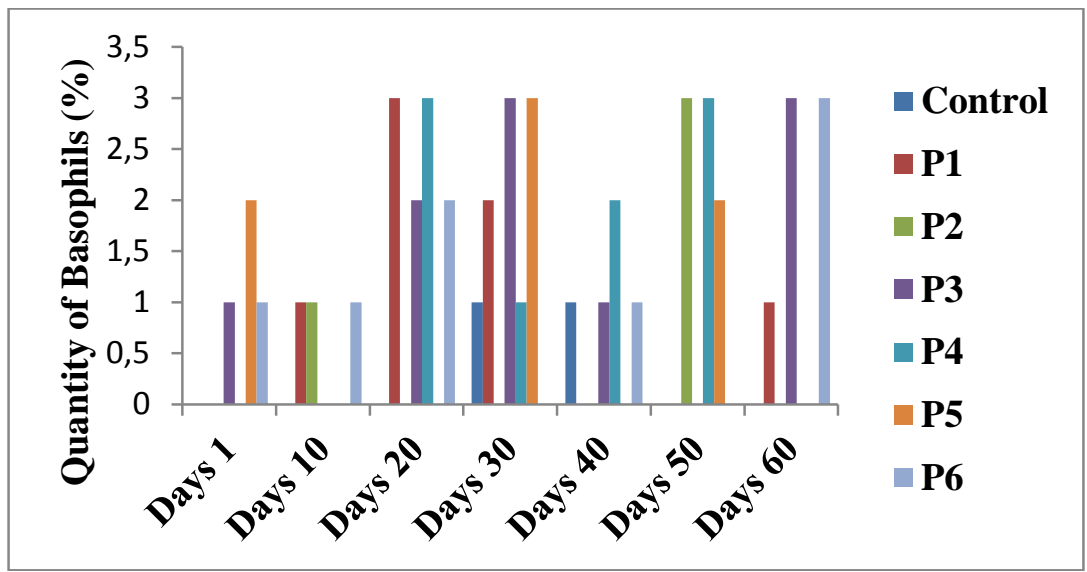

Figure 6. Quantity of basophils components

The three leukocyte component graphs shown in Figures 4, 5 and 6, have very different responses to the quantity of leukocytes, neutrophil components, and lymphocytes. The components of monocytes, eosinophils, and basophils have fluctuating responses, according to their function as phagocytes, tend to have almost the same response to radiation induction (Sutapa et al., 2014). Statistical analysis was conducted on the results of this study that the quantity of leukocytes, neutrophil components, and lymphocytes had significant difference insignificance $(\mathrm{P} \leq 0.05)$ compared to the other three components of leukocytes. According to Desprez (2011), the components of neutrophils and lymphocytes are more sensitive to radiation than the other three components of leukocytes.

\section{Conclusion}

The survival of leukocytes, neutrophil components, and lymphocytes gives a clear picture and response to cell development from day to day and the addition of the time interval for $\mathrm{AD}$ with $\mathrm{CD}$ shows an increase in the quantity of leukocytes, neutrophil components, and lymphocytes after Co-60 gamma radiation. The picture of cell survival is very important in determining the method of low-dose radiotherapy or dose adaptation.

\section{Acknowledgments}

Acknowledgments to Udayana University for funding the implementation of this research through the Unud BLU DIPA in the fiscal year 2021 following the Letter of Appointment for the University Leading Research (PUU). 


\section{References}

Alatas, Z. 2006. Biological Indicators of Damage to the Body Due to Radiation Exposure. Alara Bulletin, 4, August.

Ambrogini, P., Cuppini, R., Cuppini, C., Ciaroni, S., Cecchini, T., Ferri, P., ... \& Del Grande, P. (2000). Spatial learning affects immature granule cell survival in adult rat dentate gyrus. Neuroscience letters, $286(1), 21-24$. https://doi.org/10.1016/S0304-3940(00)01074-0

Castillejos, L., Calsamiglia, S., Ferret, A., \& Losa, R. (2007). Effects of dose and adaptation time of a specific blend of essential oil compounds on rumen fermentation. Animal Feed Science and Technology, 132(3-4), 186-201. https://doi.org/10.1016/j.anifeedsci.2006.03.023

Confer, A. W., Hall, S. M., Faulkner, C. B., Espe, B. H., Deyoe, B. L., Morton, R. J., \& Smith, R. A. (1985). Effects of challenge dose on the clinical and immune responses of cattle vaccinated with reduced doses of Brucella abortus strain 19. Veterinary microbiology, 10(6), 561-575. https://doi.org/10.1016/0378-1135(85)90065-3

Desprez, P. Y. (2011). Radio-Adaptive Response and Breast Cancer. California Pacific Medical Center Research Inst San Francisco.

Djan, I., Solajic, S., Djan, M., Vucinic, N., Popovic, D., Ilic, M., ... \& Bogdanovic, G. (2014). Radiobiological effects of multiple vs. single low-dose pre-irradiation on the HT29 cell line. Contemporary Oncology, $18(4), 230$.

Donovan, E., Bleakley, N., Denholm, E., Evans, P., Gothard, L., Hanson, J., ... \& Yarnold, J. (2007). Randomised trial of standard 2D radiotherapy (RT) versus intensity modulated radiotherapy (IMRT) in patients prescribed breast radiotherapy. Radiotherapy and Oncology, 82(3), 254-264. https://doi.org/10.1016/j.radonc.2006.12.008

Hall, E. J., \& Giaccia, A. J. (2006). Radiobiology for the Radiologist (Vol. 6).

Harahap, N. S. (2008). Pengaruh aktifitas fisik maksimal terhadap jumlah leukosit dan hitung jenis leukosit pada mencit (Mus Musculus L) jantan. USU e-ropository. Medan.

Hindséna, M., Bruzea, M., \& Christensenb, O. B. (2001). Flare-up reactions after oral challenge with nickel in relation to challenge dose and intensity and time of previous patch test reactions. Journal of the American Academy of Dermatology, 44(4), 616-623. https://doi.org/10.1067/mjd.2001.110873

Jacks, T., \& Weinberg, R. A. (2002). Taking the study of cancer cell survival to a new dimension. Cell, 111(7), 923925. https://doi.org/10.1016/S0092-8674(02)01229-1

Jacob, T. J., Fraser, C., Wang, L., Walker, V., \& O'Connor, S. (2003). Psychophysical evaluation of responses to pleasant and mal-odour stimulation in human subjects; adaptation, dose response and gender differences. International Journal of Psychophysiology,48(1), 67-80. https://doi.org/10.1016/S01678760(03)00020-5

Kadhim, M. A., Moore, S. R., \& Goodwin, E. H. (2004). Interrelationships amongst radiation-induced genomic instability, bystander effects, and the adaptive response. Mutation Research/Fundamental and Molecular Mechanisms of Mutagenesis, 568(1), 21-32.

Kusumayanti, G. D., \& Dewantari, N. M. (2017). The influence of low purine diet and physical activity on changing of uric acid levels in hyperuricemia. International Journal of Health Sciences, 1(3), 1-9. https://doi.org/10.21744/ijhs.v1i3.45

Lusiyanti, Y., \& Syaifudin, M. (2008, May). The Application of Effects of Interaction Between Radiation and Biological System as Biological Dosimeter; Penerapan Efek Interaksi Radiasi dengan Sistem Biologi sebagai Dosimeter Biologi. In Jurnal Forum Nuklir (Vol. 2).

Mayerni, M., Ahmad, A., \& Abidin, Z. (2009). Dampak Radiasi Terhadap Kesehatan Pekerja Radiasi Di Rsud Arifin Achmad, Rs Santa Maria Dan Rs Awal Bros Pekanbaru. Jurnal Ilmu Lingkungan, 7(1), 114-127.

Okazaki, R., Ootsuyama, A., \& Norimura, T. (2005). Radioadaptive response for protection against radiationinduced teratogenesis. Radiation research, 163(3), 266-270.

Pearce, P. L. (2005). Tourist behaviour: Themes and conceptual schemes. Channel View Publications.

Romero, R., Yoon, B. H., Mazor, M., Gomez, R., Diamond, M. P., Kenney, J. S., ... \& Sehgal, P. (1993). The diagnostic and prognostic value of amniotic fluid white blood cell count, glucose, interleukin- 6 , and gram stain in patients with preterm labor and intact membranes. American journal of obstetrics and gynecology, 169(4), 805816. https://doi.org/10.1016/0002-9378(93)90009-8

Schattner, A. D. G. T. S. M., Merlin, G., Levin, S., Wallach, D., Hahn, T., \& Revel, M. (1981). Assay of an interferon-induced enzyme in white blood cells as a diagnostic aid in viral diseases. The Lancet, 318(8245), 497500. https://doi.org/10.1016/S0140-6736(81)90883-7

Schwartz, D. L., Garden, A. S., Shah, S. J., Chronowski, G., Sejpal, S., Rosenthal, D. I., ... \& Dong, L. (2013). Adaptive radiotherapy for head and neck cancer-dosimetric results from a prospective clinical trial. Radiotherapy and Oncology, 106(1), 80-84. https://doi.org/10.1016/j.radonc.2012.10.010

Sisworo, G. S. (2007). Korelasi Antara Tingkat Stres Kerja Dan Hipertensi (Doctoral dissertation, Universitas Airlangga). 
Sloane, N. J. (2003). The on-line encyclopedia of integer sequences.

Sulaeman, R., Muhasidah, .-., Purnamawati, D., Zulkifli, .-., Jafar, S. R., \& Suiraoka, I. P. (2018). Progressive muscle relaxation using video aids reduces blood pressure of hypertension patients. International Journal of Health Sciences, 2(3), 33-42. https://doi.org/10.29332/ijhs.v2n3.214

Sutapa, G. N., Astra, I. M. K. A., \& Soejoko, D. S. (2014). In vivo Radioadaptive Response of White Blood Cells (Leukocytes) Quantity in Mouse (Mus musculus L) Blood to Co-60 Gamma Radiation Exposures. And Risks Of Ionizing Radiation (SERIR) BALI, 10-11 OCTOBER 2013, 1, 293. 